\title{
Participatory Digital Video for Extension Teaching
}

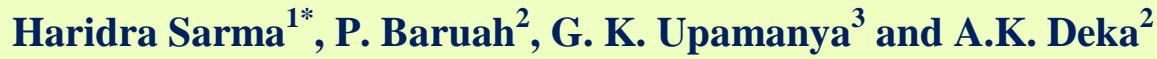 \\ ${ }^{1}$ B.N. College of Agriculture, Assam Agricultural University, Assam, India \\ ${ }^{2}$ KVK Barpeta, Assam Agricultural University, Assam, India \\ ${ }^{3}$ SCS College of Agriculture, Assam Agricultural University, Assam, India \\ *Corresponding author
}

\begin{abstract}
A B S T R A C T
Educational technology is the integration of the science of education with the advances in technologies like information and communication to address fundamental issues of teaching and learning. The present study was conducted in the Barpeta district of Assam with the objectives to develop participatory videos on mushroom and vermicompost production technologies and assess the performance of digital videos as extension teaching aid in terms of comprehensiveness, usefulness and degree of convincing. The study also assessed the constraints faced by both technical and resource persons in preparation and use of digital videos as teaching aid. Digital videos were prepared on mushroom and vermicompost production technologies with the active participation of the master trainers. The performance of the digital videos as teaching aid was assessed by showing the videos in two groups consisting of 25 numbers of trainees in each group during the training session. The comparative study using the match sampling technique was undertaken with another two groups with same numbers of respondents each in which the digital video was not shown during the training session. Results revealed that 90 per cent of the respondents trained with digital video found the message comprehensible as compared to 42 per cent of the respondents trained without the video. More than 75 per cent respondents found the videos useful, while 64 per cent respondents from the group not seeing digital video found the training useful to their vocation. Further, after viewing the videos, majority of the respondents (90 per cent) understood the procedure of vermicompost and mushroom production technologies and were convinced that these could be tried back home with locally available resources.
\end{abstract}

\section{Introduction}

Educational technology, EduTech or EdTech, is a multidimensional concept. It is a subjective concept that basically defines value addition to the educational system. Therefore, wide consensus on a definition is hardly achieved. Education technology is the study and ethical practice of facilitating learning and improving performance by creating, using and managing appropriate technological processes and resources (Richey, 2008). Education technology as an academic field is considered as integration of the science of education system, its practical knowledge with other technologies to address 
fundamental issues of teaching and learning. Thus, it implies the systematic application of scientific knowledge to practical tasks. Here, the main focus is on technological innovations. Secondly, it aims to improve effectiveness and efficiency of the education system. According to educationalists, there are three major factors that emphasize the linking of education with technology viz., exploration of population, exploration of new knowledge and explosion of scientific and technological development. However, economists have identified three factors behind use of technology in Education Industry:-

Capital deepening: the ability of the workforce to use equipments that is more productive than earlier versions.

Higher quality workforce: a more knowledgeable workforce that is able to add value to economic point

Technological innovation: the ability of the workforce to create, distribute, share and use of the new knowledge

There are numbers of technologies used as tools of teaching such as computers, class blogs and Wikipedia, wireless classroom microphones, mobile devices, interactive whiteboards, digital videos, online media and study tools, digital games etc. Digital videos are becoming popular in all the spheres of teaching-learning process. Informative and interactive videos may be utilized as a powerful tool for both child and adult education as it stimulates maximum number of senses at a time. Digital videos refer to the capturing, manipulating and storage of moving images that can be displayed on computer screens (The Lycos Tech Glossary, 1999). This requires the moving images be digitally handled by the computer. Digital video is a type of digital recording system that works by using a digital rather than an analog video signal. When used effectively, it can fascinate an audience, tug emotions, maintain attention and contextualize scenario-based learning (Bhalerao et al., 2014). Moreover, it eliminates the need for in-classroom hardware, simulates real life situations and allows teachers and students to access video clips immediately by not utilizing the public internet. The present study was undertaken to find out the efficacy of participatory digital video as a tool of extension teaching in context with the following objectives include to develop participatory videos on mushroom and vermicompost production technologies. Also to assess the performance of digital videos as extension teaching aid in terms of comprehensiveness, usefulness and degree of convincing and to find out constraints faced by both technical and resource person in preparation and use of the digital videos as teaching aid.

\section{Materials and Methods}

The Barpeta district of Assam was purposively selected to conduct the study as the district is under jurisdiction of $\mathrm{KVK}$, Barpeta. In the present study the term training and teaching is used invariably for better understanding. Under the study, participatory videos were prepared on mushroom and vermicompost production technology. To develop participatory digital video scientific procedure developed by Bhalerao et al., (2014) was followed. The videos were used as teaching aid during the training sessions. To assess the performance of the video as teaching aid, videos were shown during the training session to two groups consisting 25 numbers each. Following a match sampling technique, another two training groups were selected as respondents and videos were not shown to them. A three point continuum scale developed by Sandhu et al., (2012) to know the level of comprehension of the message i.e. comprehensible, difficult to comprehend and not comprehensible; usefulness of the message i.e. very useful, not so useful and not useful, was used. In addition to this, whether 
the videos were convincing for trying in back home condition was measured using a three point continuum scale i.e. convincing, somewhat convincing and not convincing. The responses received were then coded, processed and tabulated. The statistical procedure and tests used for analysis of the data were frequency and percentage.

For collecting information, a semi structured interview schedule (Upamanya et al., 2019) was designed and responses were recorded. Some open ended questions like "Challenges you faced as you worked on your video project, and how did you overcome them" were also framed and responses were recorded during an open discussion session from both technical persons and participants.

\section{Results and Discussion}

\section{Production of participatory digital video}

Two numbers of digital videos were prepared on Mushroom and vermicompost production technologies, with the active participation of the master trainers following the procedure mentioned below:

\section{Stage-1: Pre- Production}

Participatory discussion on the subject matter Preparation of script or storyboard

Planning on relevant and required pictures and video clips

Matter for audio tracks on message

Relevant sound tracks

Software for conversion of input and output

Stage-2: Production

Practical camera work and sound recording Editing and/or encoding the finished video Installing a video editing and movie producing software: WINDOWS MOVIE MAKER
Publishing the project as digital video

Stage-3: Post-Production

Training session on mushroom and vermicompost production technology with digital video

Training session on mushroom and vermicompost production technology without digital video

\section{Performance of digital videos as teaching aid in terms of comprehensiveness, usefulness and degree of convincing}

Perusal of data (Table 1) revealed that majority of the respondents $(90 \%)$ trained using digital videos during the training session on mushroom and vermicompost production technologies found the message comprehensible compared to only 42 per cent respondents trained without digital video found the process discernible.

Regarding the responses on usefulness of message, more than 75 per cent respondents found the digital videos useful while 18 per cent of the respondents found it not so useful. In case of the group not experiencing digital video, 64 per cent respondents found it useful to their vocation. This reduction in percentage might also be due to non realization of the need of organic agriculture by some of the respondents. In case of mushroom production technology, the perception on usefulness might be highly dependent on food habit of the community.

Data on whether the video were convincing for trying in back home condition reveals that the whole procedure on vermicompost and mushroom production technology is understood by majority of the respondents ( 90 $\%$ ) and were convinced that it could be tried at back home condition with locally available resources. On the other hand, in the group without digital video, majority of the 
respondents $(56 \%)$ expressed their confusion regarding executing the process at home.

Similar type of findings were reported by Henderson et al., (2010) and Morgan(2013) on school students, who opined that with proper implementation, digital video production as an assessment tool has myriad benefits. It helps students learn more deeply about the topic on which they are making a video.

Table.1 Performance of digital videos as teaching aid in terms of comprehensiveness, usefulness and degree of convincing

\begin{tabular}{|l|c|c|}
\hline \multirow{2}{*}{ Particulars } & \multicolumn{2}{|c|}{ Training group } \\
\cline { 2 - 3 } & $\begin{array}{c}\text { With Digital video } \\
\text { Frequency (Percentage) } \\
\text { N=50 }\end{array}$ & $\begin{array}{c}\text { Without Digital video } \\
\text { Frequency (Percentage) } \\
\text { N=50 }\end{array}$ \\
\hline Comprehensiveness & $45(90.0)$ & $21(42)$ \\
\hline Comprehensible & $2(4.0)$ & $19(38.0)$ \\
\hline Difficult to Comprehend & $3(6.0)$ & $10(20.0)$ \\
\hline Not comprehensible & & $32(64.0)$ \\
\hline Usefulness & $38(76.0)$ & $12(24.0)$ \\
\hline Useful & $9(18.0)$ & $6(12.0)$ \\
\hline Not so useful & $3(6.0)$ & $14(28.0)$ \\
\hline Not useful & & $28(56.0)$ \\
\hline Degree of convincing & $45(90.0)$ & $8(16.0)$ \\
\hline Convincing & $2(4.0)$ & \\
\hline Somewhat convincing & $3(6.0)$ & \\
\hline Not convincing & & \\
\hline
\end{tabular}

While studying the effectiveness of mediated video- based training on individuals' adoption rates of a new agricultural technology in rural Bihar, India, Vasilaky et al., (2015) reported that farmers responded to the videos which feature individuals similar to themselves operating in their local setting. The probability of adoption increases by 0.05 for those who viewed Digital Green videos, where the average adoption rate in the control group is 0.10 , a $50 \%$ increase between treatment and control groups.

\section{Challenges faced in production of digital video as teaching aid}

Following are the challenges faced during production and assessing participatory digital video as teaching aid:

Enough time and involvement is required for production of a digital video from both the participants as well as resource persons Proper knowledge on subject matter of both trainers and the participants

Requirement of sophisticated tools and machineries like Camera, Computers etc.

Availability of latest software

Lack of participants' access to knowledge on the technology

Participatory digital video production as teaching tool provides an opportunity to the stakeholders of the teaching-learning process to demonstrate their learning in an engaging way while fostering $21^{\text {st }}$ century skill like creativity, collaboration, communication and critical thinking. A successful implementation of video as teaching aid is dependent on best practices that include careful planning, clear directions and ample time to complete pre-production tasks like storyboarding, scriptwriting and learning how to use video editing technology. 
Such kind of scientifically made digital videos can be used at anytime without using public internet. It may be a promising tool for transfer of technologies. These videos can be written on CDs and DVDs and distributed amongst participants. Properly compressed digital videos uploaded on institute's website can be downloaded by clients and hence can be utilized for distance or online learning. In agriculture, besides the novel technologies some of the indigenous technical knowledge (ITK) might be transferred to the farmers of other locality using digital video. Some of the ITKs like management of potato tuber moth using traditional storage structure like topa as documented by Upamanya et al., (2014), use of killed crabs, frogs or toads in the rice fields for management of rice bug (Talukder et al., 2012) etc. will be useful to the fellow farmers if methods are documented in digital video form. The possibilities of using potential of digital video presentation are enormous and this advanced information sharing tool can definitely bring more impact in the teachinglearning process.

\section{References}

Bhalerao, A.K., Paul, S., Singha, A.K., Jat, P.C., Bordoloi, R., Gogoi, A.K. (2014) Digital video production for enhancing retention of learning among adult trainees of KVKs. Technical Brochure, ZPD, Zone-III, ICAR, Umiam.

Henderson, M., Auld, G., Holkner, B., Russell, G., Seah, W.T., Fernanado, A., Romeo, G. (2010). Students creating digital video in the primary classroom: Students autonomy, learning outcomes, and professional learning communities. Australian Educational Computing, 24(2):12-20

Lycos Tech Glossary (1999):

http://webopedia.lycos.com/Multimedia/Vi deo/video.html

Morgan, H. (2013). Creating video can lead students to many academic benefits. Childhood Education, 89(1), 51-53. Retrieved from http://go.galegroup.com.pearls.stkate.edu/ps /i.do?id=GALE\%7CA317469023\&sid=sum mon $\& v=2.1 \& u=c l i c \_s t k a t e \& i t=r \& p=I T O F$ $\& \mathrm{sw}=\mathrm{w} \& \mathrm{asid}=\mathrm{b} 84 \mathrm{a} 560 \mathrm{bc} 322 \mathrm{baf} 2 \mathrm{c} 5 \mathrm{bb} 918 \mathrm{f}$ dff641d6

Richey, R.C. ( 2008). Reflections on the 2008 AECT, Definitions of the Field. Tech Trends.

Sandhu, H.S., Singh, G., Grover, J. (2012): Analysis of Kisan Mobile Advisory Service in South Western Punjab. Journal of Krishi Vigyan, 1(1): 1-4.

Talukder, R.K., Barman, S., and Hussain, A. (2012). Documentation and perceived rationale of Indigenous Technical Knowledge (ITK) utilized in Boro rice cultivation by farmers of Kamrup District of Assam J. Acad. Indus. Res. 1(7): 412418.

Upamanya, G.K., Sarma, H. and Sarmah, A.K. (2019). Knowledge Level of Village Level Extension Workers on Biocontrol Agents and Biopesticides in Barpeta District of Assam IARJSET: 6 (12): 56-58. (DOI 10.17148/IARJSET.2019.61211)

Upamanya, G.K., Sarma, H., Sarma, R. and Helim, R. (2014). Topa: A unique storage structure for managing potato tuber moth. Asian Agri-History: 18(2): 191-194.

Vasilaky, K., Toyama, K., Baul, T., Mangal, M., Bhattacharya, U. (2015). Learning Digitally: Evaluating the Impact of Farmer Training via Mediated Videos. Retrieved from https://www.digitalgreen.org/wpcontent/uploads/2017/06/NEUDC2015519.pdf

\section{How to cite this article:}

Haridra Sarma, P. Baruah, G. K.Upamanya and Deka, A.K. 2020. Participatory Digital Video for Extension Teaching. Int.J.Curr.Microbiol.App.Sci. 9(05): 1913-1917.

doi: https://doi.org/10.20546/ijcmas.2020.905.218 